\title{
DESZTINÁCIÓ MARKETING
}

\author{
(Destination Marketing)
}

\section{KOZMA BOGLÁRKA MARIANNA}

A megatrendek számos tényezö, folyamat együttes hatásának következményei. Az egymásba kapcsolódó gazdasági, politikai, technológiai, demográfiai, szociális és kulturális folyamatok közül a térségek fejlödését elsősorban a gazdasági folyamatok katalizálják, irányítják.

A térségfejlődés, -fejlesztés egyik tényezöje a turizmus. A desztináció (fogadóterület) marketing a turizmus marketing alapja, katalizátora a turisztikai alágazatok marketingjének; minősége jelentősen determinálja a többi turisztikai ágazat eröfeszítéseinek eredményességét. A turisták utaztatása, elszállásolása, etetése egy fabatkát sem ér, az „éppen ott lenni” desztinációs faktor nélkül.

\section{A fogadóterület jellemzői, a desztináció feltételrendszere}

\section{Mi a desztináció? Hogyan lehet megkuilönböztetni az egyes fogadóterïleteket?}

A fogadóterület egy komplex, sajátos termék, amely több másik termékböl épül fel. A desztináció egy entitás, de számos - magához a földrajzi helyhez kötődő turisztikai és iparágon kívüli szervezet és közősség összessége. A desztinációval kapcsolatos fogyasztói tapasztalatok illetve image kialakulásakor az iparágon kívüli olyan tényezök is szerepet játszanak, mint a térség lakossága, az ott müködő más iparágak, a tájkép stb.

Bár a fogadóterület a központi turisztikai termék, mégis előfordulhat, hogy nem létezik a térséggel mint turisztikai termékkel megbízott fejlesztő illetve marketing szervezet. A desztináció image-ét, megitélését az összes ott müködő szervezet és személy öntudatlanul is befolyásolhatja, így a desztináció marketing mindig egy szándékos vagy nem szándékos együttmüködés a térségi szereplök között. Tudatos és sikeres térség-marketing alkalmazásakor tervezett együttmúködés, koordináció valósul meg, ekkor a desztináció marketing megfelelő keretet nyújt a többi turisztikai termék marketingjehez, illetve megteremti a közös marketing pénzügyi hátterét.

- A desztináció nemcsak fizikai entitás, hanem szocio-kulturális entitás (saját történelemmel, lakosaival, tradícióival és életmódjával) is egyben.

- A fogadóterület nemcsak a ma létezö, kézzel fogható valóság, hanem az emberek (turisták, lakosok, vállalkozások, média képviselők) fejében létezó mentális koncepció. Emiatt nagyon nagy jelentősége van a desztináció image-nek.

- A desztinációra nemcsak az ott történtek hatnak, hanem a határain túl zajló események is (háborúk, terrorizmus, járványok, küldő országok dekonjuktúrája).

- Image-ére, keresletére nemcsak a jelen, hanem a múlt eseményei is hatnak 
(pl. Pompei), image-ét nemcsak a valós események, hanem a legendák, hiedelmek is alakítják (Szentkút, Loch Ness).

A fogadóterület drágaságáról, olcsóságáról is él a turistában és a potenciális turistában egy kép. Valójában azonban nem létezik olyan objektív módszer, amely rangsorolná az egyes fogadóterületeket azok drágasága szerint.

Az egyes fogadóterületek számos jellemzőjükben különböznek (szinte lehetetlenné téve az összehasonlítást):

- Méretbeli különbségek. A desztináció egy országtól az országhatáron átnyúló szubrégiótól a néhány lelkes településig terjedhet. Több országban témaspecifikus marketinget folytatnak (pl. London Arts Tourist).

- A fogadóterület attrakció ellátottsága. Az attrakciók vonzáserỏssége és száma.

- A desztináció infrastrukturális kiépítettsége.

- A látogatóknak, turistáknak nyủjtott haszon különbözösége (rekreáció, üzlet).

- A fogadóterület turizmustól való függősége (teljes illetve kisebb mértékủ függőség a diverzifikált gazdaságú térségekben).

\section{Mitöl lesz egy területböl desztináció?}

- Teljes körủ szolgáltatási csomag, legalább egy piaci szegmenshez.

- Egyéni profil - „márka-potenciál”.

- Kielégitő piaci potenciál.

- Elegendö függetlenség a marketing mix létrehozásában és megvalósításában.

- Jól körülhatárolható versenyhelyzet.

- Behatárolt számú érdek.

- Megfelelő méret, a „méretgazdaságosság” biztositására, az együttmüködés, know-how átadás, piaci részesedés, kompetencia-kínálat stb. terén.

\section{A desztináció marketing gyakorlata}

Számos szerzö, kutatói közösség foglalkozott a desztináció marketing feladatkörének és azok sorrendiségének a meghatározásával (Seaton-Bennett 1996).

Seaton szerint a desztináció marketing öt lépéssel írható le:

1) A jelenlegi piac számbavétele, a jövőbeli piacok elörejelzése.

2) A desztináció auditálása és piaci megjelenésének, jelenlétének az elemzése.

3) A stratégiai célok és a marketing mix kidolgozása.

4) A célok végrehajtása felett bábáskodó szervezet létrehozása.

5) Az elöbbiek végrehajtása és az eredmények értékelése.

Most vizsgáljuk meg részletesebben a desztináció marketing Seaton szerinti lépéseit, valamint ezen lépések megvalósításának nehézségeit. 
A jelenlegi piac számbavétele, a jövöbeli piacok elörejelzése

A desztináció marketing a piaci elemzéssel, a fö szegmensek vizsgálatával kezdödik. Tudni kell, hogy mennyi látogató/turista érkezett a desztinációba, miért pont ide jönnek, mit akarnak tenni, és mennyit költenek. Az újonnan fejlesztendő fogadóterület a hozzá hasonló desztinációk tapasztalatát és adatait használhatja fel a tervezéskor. Azon fogadóterületeknél (például a nemzeti desztináció szintjén), ahol nemzetközi érkezésekkel is számolni kell, a világtrendek elemzése válik szükségessé.

\section{A desztináció auditálása és piaci megjelenésének, jelenlétének elemzése}

\section{Az egyedi értékesitési ajánlat (USP)}

Meg kell határozni, hogy mi lehet az a vonzerö, ami a célcsoportot a térségbe vonzza. Olyan attrakciót, USP-t kell létrehozni, ami különbözik más fogadóterület kínálatától.

A globalizáció egyik következménye, hogy a verseny a nemzetek szintjéröl régiók és alrégiók szintjére tevődik át. Ez a promóció szintjén is más megközelítést kíván. A választott image a régió ,jövó programja" kell legyen.

A USP karakterisztikus jegyei:

- egyediség,

- összetéveszthetetlenség,

- különleges vonzerő,

- úttöró jelleg,

- összehasonlíthatatlanság,

- mellbevágó,

- „mozdonyhatás”.

Azt, hogy egy térségnek van-e és milyen az USP-je, az alábbi kérdések megvitatásával dönthetjük el:

- Különleges értékekből áll, vagy hasznosságot nyújt?

- Mekkora az újdonság effektusa, illetve kreativitása és innovációs foka?

- Milyen a vonzereje, profilírozhatósága és kommunikálhatósága?

- Mekkora gerjesztő ereje van a szomszédos térségekre, mekkora az innováló képessége?

- Mennyi ideig hat a piacra és mekkora a leutánzási veszély?

\section{A fogadóterület versenyelönyének meghatározása}

A desztináció marketingeseinek meg kell határozniuk a fogadóterület versenyelönyét. Ehhez három kérdéskört kell megvizsgálni:
A) Mi van a térségben?
B) Mit gondolnak mások arról, hogy mi van a térségben?
C) Milyen a desztináció eddigi reprezentációja? 
A) Mi van a térségben? - a desztináció eröforrásai

A desztináció erőforrásait négy kategóriába sorolhatjuk:

1) A fizikai attrakciók, melyek lehetnek természeti, valamint épített, művi vonzerők.

2) A szocio-kulturális vonzerök.

3) Infrastruktúra (nem ez a fö tényező az utazási döntés meghozatalakor, de az előzetes image kialakulásakor fontos szerepet játszhat).

4) Szálláshely. Az infrastruktúra része, de jól át kell gondolni, hogy az adott turizmusforma és a célcsoport milyen szálláshelyre tart igényt.

B) Mit gondolnak mások a térségröl? - a desztináció image

A turizmus fejlesztöinek tudniuk kell, hogy mások hogyan látják a térséget, melyek azok a tényezök, amelyek alapján ítéletet hoznak. A desztináció image mindazoknak az elképzeléseknek és benyomásoknak az összessége, amit az egyének gondolnak a fogadó-területröl. Beletartozhat a térség földrajzi adottságáról, az ott élö emberekről, az infrastruktúrájáról, a klímájáról, a történelméröl, a biztonságosságáról, a vonzerői értékességéről az emberekben alkotott kép.

A desztináció image döntő tényező az úti cél választáskor, vizsgálatakor az alábbi kérdésekre keressük a választ:

- Milyen - a turisták és a potenciális turisták körében éló, tényleges - tapasztalati image-e van a desztinációnak?

- Milyen mértékben tér el a fogadóterület image-e a különbözö szegmensek esetében?

- Ez különbözik-e attól az image-töl, amit mi gondolunk róla a versenytárs desztinációk ismeretében? (Minden utazni szándékozó a végső döntést több desztináció között választva hozza meg.)

Hogyan változtathatjuk meg az image-t?

Az egyes szegmensek image vizsgálata után meg kell oldani az image fenntartásának, módosításának vagy gyökeres átalakításának problematikáját. Az image-re többféle információ hat.

A teoretikusok kétféle image forrást különböztetnek meg:

1) Organikus image forrás,

2) Indukált image forrás.

Az image jellemzöi

A desztináció image általában sztereotípiákból épül fel, ,,a más” elvárásának megfelelő hely jellemző tulajdonságait jeleníti meg. A „,más” szociálantropológusok által használt fogalom, a különbözőséget, az egzotikumot, a mindennapi élet kontrasztját jelenti. A „más" várása a turizmus fő motiváló tényezöje. E miatt adják el a fogadóterületeket azokkal a sztereotípiákkal, amelyek fö üzenete az attrakció különlegessége, egyedisége, miközben valójában - a globalizációnak „köszönhetöen” 
- minél inkább felgyorsul és térben terjed a modernizáció és az iparosodás, annál inkább csökkenek az úti célok közötti különbségek.

A sztereotipizálást két oldalról is támadják. Egyfelöl a vendéglátók közössége gyakran rossz néven veszi a kultúrájukat artikuláló marketingkommunikációs üzenetet, illetve elutasítja azt a képet, ahogyan a turisták gondolkodnak a kultúrájukról. A kutatók szintén érzékelik a távoli térségekről, főként fejlődő területekről teremtett image és a tényleges szociálpolitikai valóság között feszülő ellentétet.

A turizmus tervezỏinek nehéz a két fél kritikáit is figyelembe vevő stratégiát kialakítani a turisták hatékony vonzására. A desztinációk eladásakor keltett image inkább hasonlít egy álomvilághoz, mint a szociológiailag dokumentálható valósághoz. Nem az a fö kérdés és feladat, hogy a kommunikációs kampánynak az ott élőkben létezők image-t kell megjeleníteni a potenciális turisták felé. Egyrészt a fö feladat, olyan üzenet eljuttatása, amely alapján az elózetesen kialakult image és a tapasztalás után kialakult image között ne legyen (vagy legalábbis minimális legyen) a szakadék és ellentét. Másrészt a fó kérdés az, hogy a desztináció be tudja-e tartani az ígéreteit. A turista mit tapasztal az ott tartózkodása során, azaz milyen csomagot állítottak össze neki, mit tesznek az utazásszervezök $a$ „,desztináció kirakatába".

A fogadóterület image-e jelentősen eltér és sokkal árnyaltabb a célterületen járt, illetve a célterületen sosem járt emberek között. A desztinációt először felkeresőkben élő kép sokkal inkább sztereotípiákból áll, mint a visszatérỏ vendégben megfogalmazott image.

A jól ismert, már bevezetett fogadóteruileteknél az indukált image szerepe sokkal kisebb, mint azoknál az új vagy újra felfedezendó desztinációknál, ahol az organikus image hiányában szinte csak a turisztikai szervezetek által létrehozott image-re hagyatkozhatunk.

A fogadóterület image-ére a szájreklám hat a legerösebben. Számos tanulmány kimutatta, hogy az úti cél kiválasztásánál sokkal erösebb az informális csatorna (rokonok, barátok, referencia csoportok) hatása, mint a média hatása.

A desztináció image-ek különböznek erőségükben és változtatási képességükben. A jól felépített image nehezen és sok ráfordítással változtatható meg. Számos szappanopera mérhetöen növelte egy-egy adott desztinációba a beutazások számát (a brazil és a mexikói „szappanopera gyáraknak” köszönhetően egy-egy világsikerü sorozat után megnő az országot látogatók száma).

A desztináció image más-más az egyes célcsoportok esetében, így egy desztinációnak több image-e létezik egy idöben. A tapasztalt image függ a nemzetiségtől (kulturális különbségek), képzettségtöl, a turista korától, az utazás motivációjától, a turista elózzetes elvárásától stb.

Országos szinten a desztináció marketinggel foglalkozók egyik nagy problémája, hogy melyek azok a jellemzők, tényezők, tulajdonságok, amelyeket ki kell emelni a marketing-kommunikációban. A döntés során számos tulajdonságot és kistérséget kizárnak, neheztelést okozva azoknak, akiknek regionális érdekeltségük van az adott területen. 


\section{C) A desztináció reprezentációja}

Miután megvizsgáltuk, hogy milyen kép él másokban rólunk; illetve, hogy mi mit akarunk, fel kell tárnunk, mi jelenik meg jelenleg fogadóterületünkröl.

A reprezentáció azért nagyon fontos, mert a desztináció mint termék, annyira misztikum, mint aktualitás. Vonzása eredhet az emberi kultúra teremtette asszociációkból. A fogadóterület eladható azokkal a - desztinációban született, elhalálozott, ott alkotó, „megforduló”, a térséggel kapcsolatba hozható - személyekkel is, akik kulturális örökséget hagytak ránk, vagy nevük, bármely okból, nem merült el a múlt ködében.

Néhány turisztikai szervezet komoly kutatást folytat egy-egy desztináció reprezentációjának feltárására, e kutatómunkába sok helyi szakértő bevonható.

\section{A marketing stratégia és a marketing mix fejlesztése}

A probléma az, hogy a turizmus térségi tervezőinek nincs beleszólása a marketing mix több elemébe. A desztináció tervezök nem tudják meghatározni az árakat, kismértékben kontrolálhatják csak a szolgáltatási lánc egyes elemeit és az elosztási csatornákat, amelyeken keresztül a fogadóterületet alkotó termékeket (szálláshely, attrakció stb.) piacra viszik. A fogadóterület marketingeseinek valójában a kommunikációs politikában jut több szerep.

A desztináció marketing szervezetei - a közösségi és a privát szektor támogatása és együttmüködése

A turisztikai termék sajátossága, hogy az idegenforgalmi vállalkozások csak részben képesek azt elöállítani. A turista nem magáért a szállodai szolgáltatásért indul útnak, hanem a desztinációs faktorért (táj, éghajlat, vonzerök stb.). Az idegenforgalmi kereslet kritikus pontja tehát a fogadóterület, amihez alkalmazkodniuk kell a turisztikai vállalkozásoknak. Ha nem teszik, akkor munkájuk hatékonysága esetleges. Ezért csak a térségi szereplök illetve a szolgáltatások közvetítöinek összehangolt munkája esetén várhatunk el jogosan eredményeket.

Mivel a régió image meghatározó az úti cél kiválasztásánál, kőzponti szükségesség a térség marketingje. A privát szektornak azonban nincs elég eröforrása a térségi marketingre.

A profitorientált cégek nem vállalják fel:

- a stratégiai tervezést,

- a marketinget / márka-menedzsmentet,

- a termékfejlesztést,

- a szolgáltatási lánc egyes elemeinek összehangolását,

- a nem rentábilis termékösszetevők biztosítását (pl. információ),

- az érdekképviseletet. 


\section{Hogyan oldható meg a közös fellépés problematikája?}

Az egyik megoldás az állami szektor intervenciója. A másik megoldás, hogy ahol nincs központi finanszírozású marketing, ott maguk a fogadóterület szereplöi hozzák létre és finanszírozzák a desztináció marketing szervezetét.

1960 óta nemzetközi szinten a légitársaságok, szállodaláncok, kamarák, vasúttársaságok is jelentős szerepet játszanak egy-egy desztináció promóciójában (ez Magyarország egyes térségei esetében még valószínüsíthetően sokáig nem potenciális lehetöség).

Desztinációvá fejleszthetö-e bármely terület, térség?

A turizmus nem az egyetlen szektor, hanem egy a sok közül. Egy adott térségnél először mindig meg kell vizsgálni, hogy mely szektort érdemes fejleszteni. A desztináció marketing sohasem lehet „kalóz akció”, csak a térség többi szektorával együttmüködve érhetünk el sikert.

Tehát el lehet-e adni bármely területet, mint turisztikai terméket? Valamilyen szinten természetesen igen. De a turizmus fejlesztőinek reális értékelés után kell felelösségteljesen dönteni a fejlesztés létéről és annak irányáról.

Egyes térségek (Észak-Amerika, Európa) elvesztik a hagyományos gazdasági alapjukat, ezért a gazdaság új fejlesztési lehetőségeit keresik. Ezek a gazdaságok megmentöként tekintenek a turizmusra.

A kevés vonzerővel rendelkező térségek gyakran próbálkoznak azzal, hogy mesterségesen létrehozott attrakcióval turistákat vonzzanak. A növekvő verseny miatt azonban e mesterségesen létrehozott attrakciók sikeressége kiszámíthatatlan. A turizmus nem tekinthetö csodaszernek. Minden egyes térségben körültekintöen kell értékelni a turizmus potenciált, a saját attrakciók és a potenciális piac vizsgálatával.

Egyes helyeken kialakul a turizmustól való túlfüggőség. Ezért törekedni kell a többszektorúságra a helyi gazdaságokban is. A gazdaság diverzifikálása nemcsak gazdasági, hanem szociális szempontból is fontos. A gazdasági diverzifikációval van csak esély egy-egy ágazati recesszió negatív hatásainak a csökkentésére. Szocio-kulturális szempontból a diverzifikáció többféle tevékenységet, színesebb emberi közösséget eredményez. Egy adott ágazat (például turizmus) fejlesztésénél figyelemmel kell lenni a többi ágazat érdekeire is és viszont.

\section{Az elöbbiek végrehajtása és az eredmények értékelése}

A turizmus fejlesztése felveti azt a dilemmát, hogy a fejlesztés hogyan hat a régió idegenforgalmi vonzerejére. A fejlesztés felemészti, bekebelezi-e a térség egyediségét? A városokban a belváros rehabilitációja mindenképpen kívánatos és pozitív változásokat eredményez, ami kedvezö hatással lehet a vonzásra.

A vidéki településeken már nem ilyen egyszerủ a kérdés. (Börcsök Antal, Pusztamérges polgármestere, a pusztamérgesi turizmus ,atyja”, egyik rádió nyilatkozatában mondta el, hogy a nyugati turisták falun való megjelenése növelte a lakosság és az önkormányzat tökeerejét. A település lakosságának életminőségét javító 
betonutak elkészítése után a falu elvesztette a nyugati városlakók számára „történelmi" vonzerejét, amelyben jelentős szerepe volt a falu aszfaltmentességének).

A turizmusfejlesztés piacorientált (kereslet-orientált) megközelítése számos környezeti és szocio-kulturális problémát okoz. Ezért egyes térségekben (Bhután, Omán) a fenntartható fejlesztés koncepcióját biztosítandó termékorientált megközelítést alkalmaznak. Ennek lényege, hogy csak azokat az attrakciókat, szolgáltatásokat és szórakozási lehetőségeket kínálják fel termékként, ami megítélésük szerint minimális hatást gyakorol a helyi közösségre. Ennek megfelelöen, a marketingnek az a feladata, hogy megtalálja, és a területre vonzza azt a fogyasztói szegmenst, akit az adott termék kielégít.

\section{Irodalom}

Bergsma, T. A. (1995) Assessing Tourism potential. Netherland.

Csizmadia L.-Bucsi L.-Fekete M.-Hegedús E.-Kozma B.-Tóth Z. (1999) Nógrád megyei turisztikai termékek körének meghatározása, hasznosítási programjuk kidolgozása. Kutatási jelentés.

Gunn, C.A. (1994) Tourism Planning: Basics, Concepts, Cases. Washington, DC. Taylor and Francis.

Horner, S.-Swarbrooke, J. (1996) Marketing Tourism hospitality and leasure in Europe. Midletton, International Thomson Business Press.

Van Lier, H.N.- Taylor P.D. (eds.) (1993) New challenges in recreation and tourism planning. Amszterdam, ISOMIL.

Piskóti I.-Bernáth A.-Kozma B.-Kiss E.-Pálffy G.-Schupler H.-Borsi. K.-Kovács Zs.-Büdy L. (1996) Borsod-Abauj-Zemplén megye PR stratégiája. Szakértöi jelentés.

Piskóti I.-Dankó L.-Schupler H.-Büdy L. (1997) Régió és településmarketing. Miskolc, Miskolci Egyetem és az RMC Regionális Marketing Centrum Kft.

Ryan, C. (1991) Recreational tourism - A social science perspective. London, Routledge.

Seaton, V.-Bennett, M.M. (1996) Marketing Tourism Products: Concept, Issues and Cases. Oxford, International Thomson Business Press.

Smith, S.L.J. (1989) Tourism analysis. London, Longman Group UK Limited.

Witt, S.F.-Moutinho, L. (1989) Tourism marketing and management handbook. Prentice Hall International (UK) Ltd.

\section{DESTINATION MARKETING}

\section{BOGLÁRKA KOZMA}

One of the factors of regional development is tourism. The speciality of the tourist product is that tourism enterprises are only partially capable of its production. The tourist does not take to the road for one or the other element of the service-chain but for the destination factor. Destination marketing is the basis of tourism marketing, its quality strongly determines the efficiency of the efforts of other branches of tourism.

The author discusses the system of criteria of becoming a destination, the difficulty of comparing the performance of the certain recipient areas (differences in size, attraction supply, difference in the benefits provided for tourists, etc.). They also review the practical steps of destination marketing, the realisational problems, and snags in the individual phases.

The author highlights the necessity of regional co-operation as a hinge of successful destination marketing. The image of the destination can be influenced by numerous actors unconsciously as well as a conscious, co-ordinated regional marketing can provide for a suitable framework for the marketing of many touristic product, and can create the financial background of common marketing. Thus the critical point of tourism demand is the recipient area to which touristic enterprises have to adapt themselves. 